DE SOTO, Hernando. O mistério do capital. Rio de Janeiro: Editora Record, 2001. Capitulo 4. p. 85-123

\title{
O mistério do capital sob o enfoque político
}

\author{
* Beatriz Miranda Batisti
}

Hernando de Soto, economista peruano, em sua obra o Mistério do Capital busca esclarecer por que o capitalismo dá certo nos países desenvolvidos e fracassa no resto do mundo. No capítulo 4, afirma que há uma "cegueira política" que impede que o problema da vultosa extralegalidade seja enxergado como verdadeiro entrave ao desenvolvimento no mundo capitalista. Diante da incapacidade de mensurar a real dimensão da questão, os governos de modo geral não agem de maneira direcionada e efetiva para solucionar o problema diagnosticado pelo autor.

Soto atribui o fracasso dos padrões populacionais e leis obrigatórias nos países em desenvolvimento e extintos países comunistas a uma enorme revolução industrial que provocou migrações e crescimento exponencial para os grandes centros urbanos. Ocorre que, diante da assustadora velocidade com que tal revolução emerge e transforma, há uma resposta e adaptação lenta por parte das instituições, forçando os novos migrantes a inventarem substitutos extralegais para as leis estabelecidos. Tal fenômeno limita a esfera de transações e negociações dos possuidores de ativos, restringindo-a a acordos ad hoc com aqueles que conhecem e confiam.

Para o economista, o fracasso legal que impede pessoas empreendedoras de negociarem com estranhos malogra a divisão de trabalho e acorrenta possíveis empresários a círculos reduzidos de especialização e baixa produtividade. Defende que sem um sistema integrado formal de propriedade um governo e uma economia de mercado são inviáveis.

A marcha para as cidades e o crescimento urbano permitiu um aumento da mobilidade humana e os padrões de luxo e de consumo foram difundidos. Os motivos para a migração são difíceis de serem detectados, pois explicações diversas são oferecidas por cada país: reforma agrária, abertura do comércio internacional, terrorismo, guerrilhas, decadência moral, modernização da

\footnotetext{
* Bacharela em Direito pela Universidade Estadual de Londrina. Graduada em Administração de Empresas pela PUCPR. Mestranda em Direito Negocial pela Universidade Estadual de Londrina. emailbiabatisti@hotmail.com
} 
agricultura, menor taxa de mortalidade infantil e possibilidades de educação. Entretanto, o autor aponta como causa mais provável a melhoria das estradas e o surgimento de novos meios de comunicação que afloraram expectativas de aumento de renda e consumo.

Os trabalhadores camponeses que imigraram foram recebidos nas cidades, em sua grande maioria, com hostilidade, enfrentando não só dificuldades no acesso a moradia, mas também nos negócios formais e trabalhos legalizados.

Ao contrário do que se imagina, se existem custos para estar legalizado, estes também existem para se permanecer fora da lei. Soto afirma que o custo de operação de um negócio extralegal no Peru, por exemplo, inclui pagar 15\% da renda anual em subornos e comissões as autoridades. Na visão do autor o custo mais significativo, no entanto, são os causados em razão da ausência de instituições que criem incentivos para que as pessoas agarrem as oportunidades econômicas e sociais de se especializarem dentro do mercado.

A diferença entre os países desenvolvidos e aqueles em desenvolvimento é que enquanto nas nações do ocidente as pessoas que vivem a margem da lei são uma pequena minoria, nos demais as extralegalidade sempre foi a corrente principal.

O problema é que a maioria dos governos em grande parte das nações não está em condições de competir com o problema extralegal.

No que tange o problema da habitação, os migrantes pobres e marginalizados instalam-se em favelas, ranchos e assentamentos e acabam adotando um contato social extralegal por meio do qual vivem e trabalham, o que evidencia um desejo de levarem uma vida pacífica e produtiva. Neste contexto as organizações informais passam a assumir o papel do governo em graus variados, chegando até mesmo a se responsabilizarem pelo fornecimento de água, esgoto, eletricidade e construção de mercados.

A ideia central discutida é a de que para que os países em desenvolvimento conquistarem um sistema legal único, a Lei oficial deve adaptar-se à realidade do impulso extralegal em massa em direção a um direito de propriedade difundido. Apesar das dificuldades reveladas, Hernando de Soto afirma que tais desafios já foram enfrentados pelas nações desenvolvidas entre o século XVIII e a Segunda Guerra Mundial, demonstrando por meio de recortes históricos como políticas que promovam a harmonização e adaptação da legislação à extralegalidade têm resultados mais favoráveis do ponto de vista social do que o reforço da rigidez legal. 
Apesar de diagnosticar o problema político encoberto nos sistemas e ativos extralegais, a obra não é capaz de descortinar um caminho ideal ou único para solucionar a questão. Assim, cada país deve buscar uma normatização que seja legitimada por toda a sociedade, fazendo com que a formalidade seja vista não só como uma exigência, mas como uma oportunidade de crescimento e inclusão no mercado capitalista, convertendo capital morto em verdadeiros ativos e riquezas.

Resenha recebida em: 03/12/2014 Aprovada para publicação em: 04/12/2014

Como citar: BATISTI, Beatriz Miranda. Resenha: DE SOTO, Hernando. O mistério do capital. Rio de Janeiro: Editora Record, 2001. Capitulo 4. p. 85123 in Revista do Direito Público. Londrina, v.9, n.3, p.251-253, set./dez.2014. DOI: 10.5433/1980-511X.2014v9n3p251. 